\title{
PERAN RELAWAN PENGGEMAR (PEMUDA PENDUKUNG GENIUS UMAR-MARDISON) DALAM TIM KAMPANYE GENIUS UMAR-MARDISON PADA PEMILUKADA KOTA PARIAMAN TAHUN 2018
}

\author{
Hizbullah Husni Nasution \\ Jurusan Ilmu Politik, Fakultas Ilmu Sosial Ilmu Politik, Universitas Andalas \\ Email: hizbullahhusni@gmail.com
}

\begin{abstract}
Abstrak
Fenomena pada Pemilukada Kota Pariaman Tahun 2018, mulai muncul relawan dari kalangan anak-anak muda yang mendukung salah satu paslon Walikota dan Wakil Walikota Pariaman yang disebut dengan PENGGEMAR (Pemuda Pendukung Genius Umar-Mardison), serta berkegiatan penuh selama Pemilukada berlangsung. Penelitian ini menggunakan konsep Omoto dan Snyder, yaitu yakni ciri-ciri dari relawan organisasi. Penelitian ini menggunakan pendekatan kualitatif deskriptif. Temuan data di lapangan memperlihatkan bahwa relawan PENGGEMAR memberikan pengaruh yang baik kepada masyarakat Kota Pariaman, khususnya kepada pemilih pemula, serta mengedukasi masyarakat baik melalui dunia maya maupun di dunia nyata. Pada hakikatnya relawan PENGGEMAR diusung oleh kesukarelaan anak-anak muda di Kota Pariaman, namun hal ini tidak mentutup kemungkinan adanya konsekuensi yang di dapatkan oleh relawan PENGGEMAR itu sendiri.
\end{abstract}

Kata Kunci : Pemilukada ; Relawan ; Penggemar

\begin{abstract}
The phenomenon in Pariaman City Election in 2018, volunteers began to emerge from young people who supported one of the pairs of Mayor and Deputy Mayor of Pariaman called PENGGEMAR (Pemuda Pendukung Genius Umar-Mardison), and had full activities during the election. This study uses the concept of Omoto and Snyder, namely the characteristics of organizational volunteers. This research uses a descriptive qualitative approach. Data findings in the field show that volunteer FANS exert a good influence on the people of Kota Pariaman, especially to novice voters, and educate the public both through cyberspace and in the real world. Basically the PENGGEMAR volunteers are supported by the volunteerism of young people in the City of Pariaman, but this does not rule out the possibility of the consequences obtained by the PENGGEMAR volunteers themselves.
\end{abstract}

Keywords: Election ; Volunteer ; "Penggemar"

\section{PENDAHULUAN}

Demokrasi di era reformasi beriringan dengan tumbuhnya generasi milenial, generasi milenial merupakan generasi yang lahir antara 1981-2000 mereka yang pada saat ini berusia 19-36 tahun (Ali Hasanuddin, 2017). Secara generasi milenial mempunyai pendidikan yang lebih baik dari generasi sebelumnya (Gen-X), mereka cukup terbiasa dengan teknologi bahkan sebagian besar dari mereka sangat ahli dengan teknologi. Dengan kepercayaan diri yang tinggi, generasi milenial mampun bekerja kreatif dan sealu mempunyai energi positif di berbagai bidang, salah satunya adalah bidang sosial politik. 
Generasi milenial merupakan generasi modern yang aktif bekerja, penelitian, dan berpikir inovatif tentang organisasi, memiliki rasa optimisme dan kemauan untuk bekerja dengan kompetitif, terbuka, dan fleksibel. Era reformasi inilah generasi milenial melalui proses demokratisasi dengan mengalami pemilu legislatif, pemilu presiden, dan pemilihan kepala daerah. Kekuasuaan terdesentralisasi serta kebebasan berbicara dan berpendapat terbuka seleber-lebarnya (Ali Hasanuddin, 2017).

Menurut Gilman dan Stokes generasi milenial generasi ini kurang tertarik terlibat berpartisipasi dalam politik secara konvensional karena berbagai alasan. Oleh sebab itu mereka lebih memilih jalur yang lebih mudah diakses untuk berpartisipasi seperti menjadi relawan dan aktivis konsumen melalui media sosial. Di samping itu, generasi milenial jadi generasi penerus yang nantinya akan menjadi bagian dari pemimpin bangsa sehingga partisipasi politik mereka terhadap negara ini dari sekarang sangatlah dibutuhkan.

Maka, muncullah aksi dari kerelawanan kaum milenial yang merupakan suatu bentuk untuk mengantisipasi keapatisan berpolitik yakni dengan cara ikut serta untuk mengkawal Pemilu yang lebih bersih dan berintegritas. Dengan adanya kerelawan generasi milinial juga berpengaruh dalam ranah Pemilukada melalui sebuah aksi untuk menjadikan Pemilukada sebagai arena kontestasi yang jujur dan adil, baik itu di dunia maya maupun di dunia nyata.

Terdapat fenomena yang menarik usai Pemilukada Kota Pariaman Tahun 2018, adanya relawan dari anak-anak muda di Kota Pariaman yang mendukung calon Walikota dan Wakil Walikota Pariaman Tahun 2018, untuk menjadi Walikota dan Wakil Walikota Pariaman periode 20182023. Gerakan relawan ini nantinya akan berpangaruh bagi masyarakat di Kota Pariaman, khususnya kepada pemilih pemula. Mulai dari kegiatan mengumpulkan anak-anak muda di Kota Pariaman, yang memiliki keinginan untuk menjadikan Kota Pariaman lebih baik kedepannya, hingga mengedukasi bagi masyarakat baik dari dunia maya maupun di dunia nyata.

Pemilukada Kota Pariaman Tahun 2018 tidak hanya diisi oleh orang-orang partai saja, namun sudah ada relawan yang independen tanpa ada embel-embel partai politik. Seperti halnya relawan dari pasangan calon Genius Umar-Mardison yang disebut dengan PENGGEMAR (Pemuda Pendukung Genius UmarMardison). Sebagian besar relawan ini dari kalangan anak-anak muda di Kota Pariaman baik itu tingkat SMA maupun Mahasiswa, dengan rata-rata usia 17 - 30 tahun. PENGGEMAR ini bergerak dari mulai Genius Umar mencalonkan diri sebagai calon Walikota Pariaman, dan di pasangkan dengan wakilnya yakni Mardison hingga pemilihan usai. Pergerakan PENGGEMAR ini aktif di media sosial seperti halnya memiliki akun yang terdaftar resmi di KPU, dengan memposting hal-hal yang mengdukasi bagi masyarakat Kota Pariaman khususnya bagi pemilih pemula, serta juga aktif berkampanye di dunia nyata. 
Kegiatan ini sepenuhnya di lakukan oleh relawan PENGGEMAR yang berkoordinasi langsung dengan tim sukses Genius Umar-Mardison. Hal unik dalam gerakan PENGGEMAR ini adalah kampanye yang tidak lagi bersifat konservatif dan tradisional, dengan model kampanye yang disukai oleh anakanak muda zaman sekarang. Relawan PENGGEMAR justru ingin berinteraksi dan dilibatkan secara langsung dengan politisi dan masyarakat serta memberikan gagasan-gagasan maupun ide terbaru untuk pembangunan Kota Pariaman ke depannya.

Berdasarkan penjelasan di atas, maka peneliti akan menjawab permasalahan : bagaimana peran relawan PENGGEMAR (Pemuda Pendukung Genius Umar-Mardison) dalam tim kampanye Genius UmarMardison pada Pemilukada Kota Pariaman Tahun 2018?. Dengan demikian tujuan kajian ini ialah mendeskripsikan dan menganalisis : (1) Proses terbentuknya PENGGEMAR di Kota Pariaman. (2) Peran PENGGEMAR dalam Tim Kampanye Genius Umar-Mardison. (3) Konsekuensi politik PENGGEMAR dalam Tim Kampanye Genius Umar-Mardison.

\section{Pemilihan Umum Kepala Daerah}

Pemilihan Umum Kepala Daerah atau seringkali disebut Pemilukada, adalah bagian dari implementasi demokrasi. Demokrasi merupakan bentuk atau mekanisme sistem pemerintahan suatu negara untuk dijalankan oleh pemerintahan negara tersebut. Pelaksanaan demokrasi telah dilakukan dari dahulu di berbagai daerah di Indonesia hingga Indonesia merdeka sampai sekarang.

Kepala Daerah adalah jabatan politik yang bertugas memimpin dan menggerakkan lajunya roda pemerintahan. Pelaksanaan Pemilukada secara langsung merupakan koreksi atas pelaksanaan pemilihan kepala daerah melalui perwakilan rakyat di DPRD berdasarkan Undang-undang Nomor 22 Tahun 1999 tentang Pemerintahan Daerah.

Koreksi atas sistem pemilihan kepala daerah ini dilakukan dengan diimplementasikannya hukum pelaksanaan pemilihan kepala daerah secara langsung, yakni UndangUndang Nomor 23 Tahun 2014 tentang Pemerintahan Daerah yang berbunyi sebagai berikut.

Dalam Undang-undang Nomor 23 Tahun 2014 tentang Pemeritahan Daerah, pemilihan kepala daerah tidak lagi dipilih melalui sistem perwakilan oleh DPRD, namun dipilih secara langsung oleh rakyat. Ini berarti pemilihan kepala daerah secara langsung memberi peluang bagi rakyat untuk ikut berpartisipasi dalam proses pengambilan keputusan yang sangat strategis dalam penyelenggaraan pemerintahan daerah melalui pemilihan kepala daerah secara langsung.

Pemilihan kepala daerah secara langsung memiliki hubungan yang sangat erat dengan pelaksanaan kedaulatan rakyat. Dengan pemilihan kepala daerah secara langsung, rakyat dapat menentukan sendiri pemimpin di daerahnya, sehingga terjalin hubungan 
yang erat antara kepala daerah dengan rakyat yang dapat mendorong terwujudnya penyelenggaraan pemerintahan daerah yang demokratis dan partisipatif.

Menurut Robert Dahl, Samuel Huntington (1993) seperti yang dikutip oleh Nopyandri (2014) mekanisme pemilihan kepala daerah disebut demokratis apabila memenuhi beberapa parameter. Parameter untuk mengamati terwujudnya demokrasi antara lain: Pemilihan Umum, Rotasi Kekuasaan, Rekrutmen Secara Terbuka, serta Akuntabilitas Publik.

\section{Kampanye}

Penyelenggaraan Pemilukada tidak terlepas dari dari kegiatan kampanye, yang dilakasanakan masing-masing partai. Menurut Roger and Storey yang dikuip oleh Apriatni EP (2008) kampanye ialah sebagai serangkaian tindakan komunikasi yang terencana dengan tujuan menciptakan efek tertentu pada sejumlah besar khalayak yang dilakukan dengan cara berkelanjutan pada kurun waktu tertentu. Terkait penyelenggaraan pemilu, berarti kampanye merupakan kegiatan komunikasi yang dilakukan oleh tim sukses dari partai politik dengan tujuan tertentu.

Kampanye bukanlah hal yang tidak direncanakan, melainkan harus dilakukan dengan konsep yang matang, dan bahkan setiap tahapan harus diperhatikan secara seksama. Setiap gagasan yang ada dalam kampanye harus dapat dipertanggungjawabkan dan siap untuk diperdebatkan. Menurut Larson (1993) ada lima tahapan dalam proses kampanye, Pertama tahap identifikasi, yaitu tahap penciptaan identitas kampanye yang dengan mudah dikenali semua khalayak, hal ini umum digunakan sebagai identitas kampanye, seperti penentuan warna, logo, seragam dan slogan, Kedua tahap legitimasi, dalam kampanye politik, legitimasi diperoleh seseorang yang telah disyahkan secara resmi oleh komisi, Ketiga tahap partisipasi, yaitu kandidat mendapat dukungan nyata secara pasrtispatif dari khalayak, baik bersifat nyata maupun simbolik, Keempat tahap penetrasi, yaitu kandidat telah lahir dan mendapatkan tempat dihati masyrakat, tim kampanye misalnya telah berhasil menarik simpati khalayak dan meyakinkan mereka bahwa kandidat adalah yang terbaik, Kelima tahapan pembuktian, pada tahap ini merupakan pembuktian akan janjijanji yang pernah disampaikan kepada khalayak, karena pada tahap ini kandidat yang terpilih tinggal membuktikan saja.

Menurut Ostergaard (2002) dalam kampanye ada 3A yang dikutip oleh Apritni EF (2008) yang perlu diperhatikan:

1. Awareness yakni menggugah kesadaran, menarik perhatian dan memberikan informasi tentang produk atau gagasan yang dikampanyekan.

2. Attitude sasarannya adalah untuk memunculkan simpati, rasa suka, kepedulian atau keberpihakan khalayak pada isu-isu yang menjadi tema kampanye.

3. Action ditujukan untuk mengubah perilaku khalayak secara konkret dan terukur. 
Dalam Pemilukada hendaknya kampanye ini tidak menjadikan sumber konflik antar tim sukses maupun kandidat yang ikut dalam kontestati politik, demi menjaga keutuhan Negara Kesatuan Republik Indonesia.

\section{Kampanye di media sosial}

Menurut Peraturan Komisi Pemilihan Umum Republik Indonesia No. 4 Tahun 2017 tentang Kampanye Pemilihan Gubernur dan Wakil Gubernur, Bupati dan Wakil Bupati, Walikota dan Wakil Walikota. Media sosial adalah kumpulan saluran komunikasi dalam jaringan internet yang digunakan untuk interaksi dan berbagi konten berbasis komunitas.

Bagi Pasangan Calon yang ingin berkampanye di media sosial harus mendaftarkan terlebih dahulu akun media sosial secara resmi yang dijadikan sebagai media untuk berkampanye, jumlah akun media sosial dapat disesuaikan. Ini bertujuan untuk mengantisipasi kampanye bermuatan negatif, dan memudahkan KPU dan Bawasalu melakukan pematauan. Adapun materi dari kampanye dalam media sosial sebagaimana yang tertera dalam PKPU No 4 Tahun 2017 pasal 48 : a. Tulisan, b. Suara, c. Gambar, d. Tulisan dan gambar, dan/atau, e. Suara dan gambar

Adapun bentuk larangan dan sanksi berkampanye di media sosial pasal 68 (1) Dalam Kampanye dilarang: a. mempersoalkan dasar negara Pancasila dan Pembukaan Undang-Undang Dasar Negara Republik Indonesia Tahun 1945; b. menghina seseorang, agama, suku, ras, golongan, Pasangan Calon Gubernur dan Wakil Gubernur, Pasangan Calon Bupati dan Wakil Bupati, Pasangan Calon Walikota dan Wakil Walikota, dan/atau Partai Politik; c. melakukan Kampanye berupa menghasut, memfitnah, mengadu domba Partai Politik, perseorangan, dan/atau kelompok masyarakat; d. menggunakan kekerasan, ancaman kekerasan atau menganjurkan penggunaan kekerasan kepada perseorangan, kelompok masyarakat dan/atau Partai Politik; e. mengganggu keamanan, ketentraman, dan ketertiban umum; f. mengancam dan menganjurkan penggunaan kekerasan untuk mengambil alih kekuasaan dari pemerintahan yang sah.

Setiap Pasangan Calon dan Tim pemenangan harus berhati-hati dan bijaksana dalam menggunakan media sosial, terutama jika membuat konten-konten tentang kampanye, karena sangksi hukum akan efektif berlaku apabila pihak-pihak tertentu menggunakan media sosial untuk kampanye-kampanye yang tidak sesuai dengan ketentuan yag berlaku. Pasangan Calon atau Tim Kampanye di media sosial wajib menutup akun resmi di media sosial paling lambat 1 (satu) hari setelah masa kampanye berkahir.

\section{Kampanye dari kaum Millennial}

Melihat karakteristik yang kuat dari kaum milenial yaitu tingginya angka literasi dan keterlibatan mereka dengan internet. Menurut Boston Consulting Group (BCG) dalam penelitian "Milenials Amerika 2011: Menguraikan Generasi Enigma" sekitar 57\% milenial Amerika termasuk di antara kelompok pertama yang mencoba teknologi baru, aktiftas online mereka dalam mengunggah dan membuat konten mulai dari foto, 
blog, blog mikro, dan lainnya sangatlah tinggi $60 \%$ sedangkan kelompok non- milenial sebanyak $29 \%$.

Menurut Pusat Penelitian Alvara Indonesia generesi milenial Indonesia hampir memiliki persamaan dengan milenial Amerika. milenial Indonesia memanfaatkan sumber digital untuk mengetahui dan memahami politik dengan mengandalkan akun media sosial twtitter, facebook, instagram, YouTube, Line, WhatsApp untuk membentuk persepsi kaum milenial tentang politik.

Namun banyak sekali kekeliruan pandangan terhadap kaum milenial yang dianggap tidak tertarik dengan politik. Maka daripada itu bentuk dukungan dari kaum milenial ialah dengan cara berpartisipasi dan terlibat secara langsung menjadi salah satu sayap muda dari Pasangan Calon. Inilah bentuk keikutsertaan dari kaum milenial terhadap perpolitikan yaitu aktif berkampanye di media sosial.

\section{Kerelawanan}

Terdapat tiga kata yang saling beririsan terkait dengan kerelawanan, yakni sukarela, altruisme (mementingkan orang lain), dan kerelawanaan itu sendiri. Dalam Kamus Besar Bahasa Indonesia kata relawan berasal dari kata sukarelawan yang artinya orang yang melakukan sesuatu dengan sukarela (tidak karena diwajibkan atau dipaksakan). Dalam artikel Muhamad Isnani kerelawanan menurut Leventhal (2009) terfokus pada aspek membantu orang lain tanpa maksud untuk memperoleh balasan materi, tetapi sesuai keingian dari yang membantu itu. Pilihan dan keinginan merupakan fondasi dasar kerelawanan.

United Nations Volunteer mengutipn Muhamad Isnani (2017) menyebutkan bahwa kerelawanan dapat digambarkan sebagai tindakan memberi tanpa mengharapkan imbalan apapun. Kerelawanan dapat dibagi menjadi empat, yakni bantuan dari diri sendiri, filantrofi atau layanan bagi orang lain, partisipasi masyarakat, dan advokasi atau kampanye.

Relawan politik di ranah media sosial dibagi menjadi dua kriteria yaitu relawan komunitas dan relawan non-komunitas. Relawan komunitas memiliki struktur dan ada pula yang hanya memiliki satu koordinator, hingga struktur kepengurusan dari tingkat pusat dan daerah. Relawan jenis ini juga memiliki nama, tempat dan visi misi organisasi. Sedangkan relawan nonkomunitas bergerak dan melakukan strategi sendiri secara mandiri. Seperti halnya aksi yang dilakukan oleh salah seorang relawan saja, tanpa ada struktur kepengurusan.

Ciri-ciri Relawan menurut Omoto \& Snyder (2008) dalam Misgiyanti, antara lain: Pertama, tindakan relawan harus bersifat sukarela, dilakukan atas dasar kebebasan tanpa ikatan kewajiban atau paksaan. Relawan dapat mengembangkan hubungan pribadi dengan sukarelawan lain, dengan anggota lembaga, atau dengan orangorang yang menerima bantuan mereka. Kedua, tindakan sukarela untuk memberikan layanan bagi orang lain atau untuk tujuan lebih lanjut melibatkan sejumlah pertimbangan atau pengambilan keputusan. Ketiga, kegiatan sukarela harus dilakukan selama periode waktu 
tertentu, dengan minat khusus untuk membantu dengan dampak kegiatan yang meluas. Keempat, keputusan untuk menjadi sukarelawan didasarkan sepenuhnya pada tujuan pribadi seseorang tanpa harapan penghargaan atau hukuman. Kelima, relawan melibatkan kegiatan melayani orang atau sebab yang menginginkan bantuan. Dalam arti lain bahwasannya layanan yang diberikan oleh sukarelawan tidak boleh dipaksakan, namun harus dengan sukarela dicari atau diterima oleh penerima.

\section{Generasi Milenial}

Menurut Ali Hasanuddin, bahwasannya generasi milenial merupakan generasi yang lahir antara tahun 1981-2000, yang pada saat ini (tahun 2019) adalah mereka yang berusia 19-36 tahun. Generasi milenial merupakan generasi setalah generasi x (yang lahir antara tahun 1965-1980), generasi milenial saat ini berperan sebagai mahasiswa, earlt jobber, dan orangtua muda. Menurut data BPS yang dikeluarkan pada tahun 2013, jumlah milenial di Indonesia pada tahun 2015 diperkirakan mencapai 33\% dari total jumlah penduduk Indonesia.

Di tahun 2020, proporsi milenial Indonesia bisa mencapai 34\% mereka akan berada pada usia 20 hingga 40 tahun. Pada tahun tersebutlah, generasi milenial akan menjadi tulang punggung perekonomian Indonesia karena mulai berkurangnya Gen-X dan Baby Boomer. Secara merata generasi milenial mempunyai pendidikan yang lebih baik dari para generasi sebelumnya (gen $\mathrm{x}$ ), mereka cukup terbiasa dengan teknologi bahkan sebagian besar dari mereka sangat ahli dengan teknologi. Dengan kepercayaan diri yang tinggi, generasi milenial mampu bekerja kreatif dan selalu mempunyai energi positif di berbagai bidang, salah satunya adalah bidang sosial politik.

Generasi milenial merupakan generasi modern yang aktif bekerja, penelitian, dan berpikir inovatif tentang organisasi, memiliki rasa optimisme dan kemauan untuk bekerja dengan kompetitif, terbuka, dan fleksibel. Era reformasi inilah generasi milenial melalui proses demokratisasi dengan mengalami pemilu legislatif, pemilihan presiden, dan pemilihan kepala daerah. Kekuasaan terdesentralisasi serta kebebasan berbicara dan berpendapat terbuka seleber-lebarnya.

Menurut Tapscott (2013), ciri khas generasi milenial adalah mudah berinteraksi dengan beragam media hanya melalui alat berlayar ukuran dua inci. Mereka menggunakan ponsel untuk beragam aktifitas. Untuk berbicara, mengecek dan membalas surat elektronik. Mereka menggunakan ponsel untuk kirim pesan, berselancar di dunia maya, bermain game, mencari arah atau jalan, mengambil gambar dan membuat video. Mereka ber-Facebook setiap saat, termasuk saat bekerja atau belajar, atau memberitahukan status mereka melalui Twitter kapan pun mereka mau.

\section{METODE PENELITIAN}

Penelitian ini menggunakan pendekatan kualitatif, jenis penelitian ini menggunakan metode studi kasus dengan tipe deskriptif. Lokasi penelitian adalah di Kota Pariaman. Teknik pengumpulan informan dengan cara purposive sampling. Penelitian 
dilakukan dengan cara terjun langsung ke lapangan mewawancarai beberapa informan atau peneliti terlibat langsung dalam proses pengumpulan data.

\section{HASIL DAN PEMBAHASAN}

Generasi milenial kerap memiliki aspirasi yang berbeda dengan dengan aspirasi dari masyarakay pada umumnya. Mereka cenderung memiliki semangat pembaharu yang kreatif dan inovatif. Peran akftif ini diwujudkan dalam bentuk agen perubahan, yang membawa perubahan ke arah yang lebih baik lagi. Adapun peran yang dilakukan oleh generasi milenial ialah menjadi relawan politik.

Fenomena relawan PENGGEMAR terbentuk dari inisiasi anak-anak muda di Kota Pariaman yang ingin mendukung Genius Umar-Mardison untuk maju dalam Pemilukada Kota Pariaman periode 2018-2023, dukungan ini adalah suatu bentuk wadah partisipasi anak-anak muda di Kota Pariaman yang menolak apatisme politik dan aprsiasi dari kaumkaum muda di Kota Pariaman kepada Genius Umar-Mardison. Jika dibandingkan dengan tahun sebelumnya, meskipun anak-anak muda di Kota Pariaman ikut terlibat dalam kampanye di Tahun 2013 namun kurang begitu masif, tidak sebanding dengan anak-anak muda di Tahun 2018. Dalam artian pada Pemilukada Tahun 2018 pemuda atau usia muda dan pemilih pemula memiliki peranan penting dalam menentukan siapa pemimpin daripada daerahnya untuk 5 tahun ke depan dan mengkawal penuh proses Pemilukada, Di Tahun 2013 sendiri masih dihuni oleh kalangan-kalangan tua yang mendominasi proses atau pola kampanye dari pada Pemilukada tersebut sehingga pola kampanye yang digunakan cenderung ke arah yang masih konservatif atau terlihat lebih kaku.

PENGGEMAR dibentuk oleh enam orang generasi milenial yakninya Febrian Mirdani, Eki Satria, Hidayat Saputra, Fernando Anggiatman, Dharma Syoergana, dan Fandy Chandra Pratama. Dari beberapa pasangan calon yang berkompetisi di ajang Pemilukada Kota Pariaman Tahun 2018, tidak begitu banyak yang menggunakan anak-anak muda yang ikut terlibat dalam kampanye mereka, seperti pasangan calon Dewi-Pebrisal dan MahyudinRidwan. Dewi-Pebrisal sendiri kurang begitu aktif berkampanye di media sosial dan tidak melibatkan anak-anak muda untuk kampanye mereka, mereka cendurung kampanye ke arah yang konservatif dan kaku. Beda halnya dengan Mahyudin-Ridwan, kampanye yang dibawakan oleh pasangan calon ini lebih ke arah yang se ideologi dengan mereka, karena basis dari pasangan calon Mahyudin-Ridwan ini adalah PKS, mereka mencari anak-anak muda yang cenderung merangkul anak-anak muda yang memiliki tujuan dengan mereka, tidak melibatkan anakanak muda secara umumnya. Adapun kegiatan dari Mahyudin-Ridwan yang aktif di media sosial tidak se aktif dari relawan PENGGEMAR, mereka lebih aktif pada saat dua bulan mejelang Pemilukada usai.

\section{Kegiatan PENGGEMAR}

Adapun kegiatan selama proses Pemilukada berlangsung PENGGEMAR tampak begitu aktif berkampanye di media sosial dengan menyebarkan konten-konten yang 
mengedukatif serta manarik perhatian khususnya bagi pemilih pemula, selain aktif kampanye di media sosial PENGGEMAR juga aktif kampanye di dunia nyata. Kegiatan ini terus berkembang dengan cara mengumpulkan jejaring komunitas yang sama-sama memiliki ideologi dan tujuan untuk mendukung Genius Umar-Mardison, seperti halnya Pariaman Socity Club (PSC), kader Pramuka, maupun dari komunitas kesenian. Hal ini untuk mengoptimalkan kegiatan

PENGGEMAR dengan memanfaatkan sumber daya manusia yanga ada. Melakukan survei Pemilukada di Kota Pariaman guna melihat elektabiltas dari Genius Umar-Mardison, kegiatan survei ini didanai oleh tim sukses sendiri dan dikelola oleh PENGGEMAR, adapun kegiatan ini dilakukan seminggu sebelum hari pemilihan, serta melakukan pelatihan saksi TPS. Semua itu dilakukan oleh PENGGEMAR dan di bantu oleh tim sukses dari Genius Umar-Mardison itu sendiri.

\section{Konsekuensi Politik PENGgEMAR}

PENGGEMAR memang bentuk dukungan dari anak-anak muda yang independen tidak terlibat oleh embel-embel partai politik apapun, setiap kegiatan memang disokong dana dari tim sukses sendiri, namun satu hal yang menarik PENGGEMAR ini tidak diberi biaya perbulannya, serta tidak ada janji politik yang disepakati sebelumnya, hanya saja upah jerih payah saja selama kampanye, dan itupun tidak ada patokannya yang diberikan oleh Tim Sukses kepada PENGGEMAR. Usai Pemilukada selesai PENGGEMAR ini tetap diberi fasilitas untuk bergerak bersama pemuda-pemuda di Kota Pariaman seperti halnya PENGGEMAR diberikan ruang untuk beraktifitas dalam sebuah bentuk forum yakninya Forum Youth Center Kota Pariaman, dan forum ini adalah bentuk inisiasi dari PENGGEMAR yang bekerja sama dengan tim sukses dan di terima dengan baik serta direalisasikan langsung oleh Genius UmarMardison.

Gerakan keralawan ini adalah suatu bentuk partisipasi anak-anak muda yang terjun langsung di dalam dunia perpolitikan di daerah. Gerakan relawan PENGGEMAR yang mendukung Genius UmarMardison merupakan bentuk kesukarelaan politik dalam demokrasi. Partisipasi dari relawan milenial ini tersebut tentunya mempunyai dasar yang kuat, salah satunya adalah keinginan kuat dari para relawan untuk memajukan Genius Umar-Mardison menjadi Walikota dan Wakil Walikota Pariaman periode 2018-2023.

\section{KESIMPULAN}

Berdasarkan dari hasil pembahasan di atas. Pada Pemilukada Kota Pariaman Tahun 2018, muncul gerakan dari relawan PENGGEMAR (Pemuda Pendukung Genius Umar-Mardison) yang ingin berpartisipasi langsung dalam dunia perpolitikan, yang digagas oleh anakanak muda di Kota Pariaman yang bertujuan untuk mendukung penuh Genius Umar-Mardison menjadi Walikota dan Wakil Walikota Pariaman periode 20182023. Relawan ini dibentuk sejak Genius Umar mencalonkan diri sebagai calon Walikota Pariaman, dan dipasangkan dengan wakilnya yakni Mardison. Kegiatan itu terus berlanjut mulai dari mengumpulkan jejaring komunitas kepemudaan di Kota Pariaman guna 
menambah sumber daya manusia. Adapun kegiatan relawan PENGGEMAR ini aktif berkampanye di dunia maya dan di dunia nyata, seperti halnya mengedukasi masyarakat di Kota Pariaman khususnya bagi kalangan pemilih pemula dengan memposting kentenkonten yang kreatif dan inovatif dari akun resmi PENGGEMAR yang terdaftar di KPU, bentuk kegiatan nyata yang dilakukan PENGGEMAR sendiri ialah menjaring komunitaskomunitas di Kota Pariaman, melakukan survei Pemilukada Kota Pariaman Tahun 2018, melatih saksisaksi untuk di TPS, serta melalukan real count. Pada dasarnya relawan ini dibentuk oleh dasar kesukarelaan, tidak pernah diberikan janji ataupun dealdealan politik sebelumnya. Setiap kegiatan relawan

PENGGEMAR didukung penuh oleh tim sukses sendiri maupun Genius UmarMardison. Pada akhirnya relawan ini benar-benar dilirik dan diberikan kesempatan khusus untuk mengelola kegiatan kepemudaan serta diberikan hal penuh untuk mengelola Forum Youth Center Kota Pariaman usai terpilihnya Genius Umar-Mardison sebagai Walikota dan Wakil Walikota Pariaman periode 2018-2023.

\section{DAFTAR PUSTAKA}

Ali, Hasanuddin dkk.2017. “Millennial Nusantara, Jakarta. Penerbit Gramedia Pustaka Utama.

Apriatni EP. 2008. Etika Terapan Dalam Kampanye Pilkada. Jurnal Forum Majalah Pengembangan Ilmu Sosial Vol 36 No 2 Juni 2008. Arianto, Bambang. 2016. "Menakar Peran Relawan Politik Pasca Konstetasi Presidensial 2014", Jurnal Ilmu Sosial dan Ilmu Politik, Volume 20, Nomor 1, Juli 2016.

Astuti, Rika Windy. 2014. "Keluarga Berencana Dalam Persepsi Kader Partai Keadilan Sejahtera (Studi Pada Keluarga Kader PKS di Desa CandimasNatar))", Skripsi dari jurusan Sosiologi Fakultas Ilmu Sosial Ilmu Politik Universitas Lampung.

Ayo Ke Pariaman, 2018, "Catatan Ringan Kemenangan Genius Umat Mardison Di Pilkada Pariaman 2018", diakses dari https://www.ayokepariaman.i d/2018/07/04/catatan-ringankemanangan-genius-umarmardison-dipilkadapariaman-2018/

Bungin, Burhan. 2006. Metode Penelitian Kualitatif. Jakarta. Rajawali Pers.

Canang News, 2018, "Melawan Berita Bohong Hoax Dan Ujaran Kebencian", diakses dari http://www.canangnews.com/ 2018/03/melawan-beritabohong-hoaxdanujaran.html?m=1 Generasi Milenial: Kassus Pada Pemilihan Kepala Daerah (Pilkada) Jakarta 2017 Dalam Perspektif Komunikasi Politik, Jurnal Komunikasi Dalam Keragaman., Jakarta.

Juditha, Christiany dan Josep Darmawan. 2018. Penggunaan Media Digital Dan Partisipasi Politik Generasi Milenial” Jurnal Penelitian Komunikasi dan Opini Publik Vol. 22 No. 2, Desember 2018, hal. 93.

Mamang Etta Sungadji dkk, 2010. Metodologi Penelitian. Yogyakarta. CV Andi Offset. Marzuki. 2005. Metodologi Riset, Panduan Penelitian Bidang Bisnis dan Sosial, Ekonisia, Yogyakarta. 
Moleong, Lexy J. 2014. Bandung. Metodologi Penelitian Kualitatif. PT.

Remaja Rosdakarya.

Nopyandri, Pemilihan Kepala Daerah Yang Demokratis Dalam Perspektif UUD 1945. Jurnal Ilmu Hukum Vol 2 No 2 News M Klik Positif, 2018, “Kapolres Pilkada Pariaman Berpotensi Konflik Hidanri Hoax dan Sara", diakses dari http://news.m.klikpositif.com/baca/27173/kapolres-pilkada-pariamanberpotensikonflik--hindari-hoax-dansara

Pariamankota.go.id "Portal Pemerintah Kota Pariaman", diakses dari pariamankota.go.id/profil/kat egori/id=1.

Peraturan Komisi Pemilihan Umum Nomor 4 Tahun 2017 tentang Kampanye Pemilihan Gubernur dan Wakil Gubernur, Bupati dan Wakil Bupati, Walikota dan Wakil Walikota.

Pemerintah Indonesia. 2014. Undang-Undang Nomor 23 Tahun 2014 tentang Pemerintahan Daerah. Lembaran Negara RI Tahun 2014 Nomor 245. Seketariat Negara. Jakarta.

Pemerintahan Indonesia. 2011. Undang-Undang Nomor 15 Tahun 2011 tentang Penyelenggaraan Pemilu. Lembaran Negara Republik Indonesia Tahun 2011 Nomor 101. Seketariat Negara. Jakarta.

Prasetyanti, Retnayu. 2017. Generasi Millennial Dan Inovasi Jejaring Demokrasi Teman Ahok. Jurnal Polinter Prodi Ilmu Politik FISIP UTA’45 Jakarta Vol. 3 No. 1 (MaretAgustus 2017).

Prokaba, 2018, "Calon Walikota Ini Laporkan Pemilik Akun Ata Ke Polisi", diakses dari https://prokabar.com/calonwalikota-ini-laporkanpemilik-akun-atake-polisi/

Rini Rizkiawati dkk. Pentingnya Buku Panduan bagi Volunteer pada Organisasi Sosial (Studi Kasus Pada Lembaga Rehabilitasi Odha dan Konsumen Napza Rumah Cemara Kota Bandung) Jurnal Social Work Vol. 7 Nomor 2.

Rojaby, Uky Dzatalini. 2018. Apatisme Generasi Milenial Terhadap Politik (Studi Kasus Kodok AlasPada Pilgub Jatim 2018). Skripsi Filsafat Politik Islam Fakultas Ushuluddin Dan Filsafat Universitas Islam Negeri Sunan Ampel Surabaya.

Saputra, Bakti. 2016. Kekalahan Tobroni Harun-Komarunizar dalam Pemilihan Kepala Derah Kota Bandar Lampung 2015. Skripsi dari FISIP Universitas Lampung, 2016,

Satori, Djam'an. 2009. Metode Penelitian Kualitatif Bandung. Alfabeta.

Sugiyono. 2016. Bandung. Metode Penelitian Kuantitaif, Kualitatif, $R \& D$. Alfabeta.

Tirto Id, 2018, "Dua ASN Pariaman kena sanksi karena dinilai tak netral saat pilkada", diakses dari https://tirto.id/dua-asnpariaman-kena-sanskikarena-dinilai-taknetral-saatpilkada-cNgg

Yin, Robert K. 2008, “Studi Kasus (Desain dan Metode). Jakarta: PT Raja Grafinfo Persada. 